\title{
Analisis Dan Perancangan Sistem E-Commerce Berbasis Cloud Enterprise Resource Planning Menggunakan Odoo 14
}

\author{
Muhamad Femy Mulya ${ }^{1}$, Nofita Rismawati ${ }^{2}$ \\ ${ }^{1}$ Program Studi Sistem Informasi, Tanri Abeng University, Jakarta, Indonesia \\ femy.mulya@tau.ac.id \\ ${ }^{2}$ Program Studi Teknik Informatika, Universitas Indraprasta PGRI, Jakarta, Indonesia \\ novi.9001@gmail.com
}

Diterima : 31 Agustus 2021

Disetujui : 28 September 2021

\begin{abstract}
E-commerce atau biasa disebut perdagangan elektronik merupakan penyebaran, pembelian, penjualan, pemasaran barang dan jasa melalui media internet atau online. Bisnis $e$-commerce terus berkembang di Indonesia, tidak hanya memfasilitasi kebutuhan konsumen, namun juga menjembatani UMKM untuk terhubung luas dengan calon konsumen potensial. Setiap organisasi atau perusahaan $e$ commerce menghadapi tantangan yang sama, yaitu kompetisi dalam dunia bisnis, namun di waktu yang bersamaan juga dituntut untuk tetap fleksibel. Untuk menghadapi tantangan tersebut, organisasi atau perusahaan membutuhkan solusi yang dapat menyimpan dan mengakses informasi dalam satu platform yang terintegrasi, agar proses bisnis menjadi fleksibel. ERP (Enterprise Resource Planning) merupakan sebuah perangkat lunak atau software yang berfungsi untuk mengelola berbagai aktivitas manajemen proses bisnis dalam suatu organisasi atau perusahaan, sehingga akan membantu pengelola e-commerce dalam mengintegrasikan sistem $e$-commerce dengan sistem lainnya. Tujuan dari penelitian ini adalah untuk menganalisa, merancang dan menggabungkan suatu sistem e-commerce yang terintegrasi dengan sistem manajemen inventory/persediaan, sistem manajemen purchasing/pembelian dan sistem manajemen penjualan pada sistem e-commerce dengan menggunakan software Odoo 14 yang sudah support dengan Cloud ERP, sehingga sistem dapat dijalankan secara optimal dan dapat mengurangi biaya-biaya operasional yang tidak efisien. Hasil dari penelitian ini adalah sistem $e$ commerce yang sudah terintegrasi dengan manajemen proses bisnis ERP yang disimpan di dalam sistem cloud, sehingga sistem e-commerce mudah diakses dan diintegrasikan dengan sistem lainnya. Pada penelitian ini juga, menggunakan metode pengujian black box dengan beberapa parameter test case/kelas uji.
\end{abstract}

Keyword: E-commerce, Cloud ERP, Odoo 14

\section{PENDAHULUAN}

Dunia bisnis semakin berkembang dengan pesat, seiring dengan kehadiran e-commerce di Indonesia. Dahulu, kegiatan transaksi dilakukan dengan cara tatap muka langsung antara pihak penjual dan pembeli, kemudian melakukan negosiasi harga untuk mendapatkan kesepakatan, lalu terjadilah transaksi antara penjual dan pembeli tersebut. Saat ini, cara yang demikian sudah mulai tergantikan, dengan adanya perkembangan dunia digital yang menggantikan keseluruhan transaksi yang bersifat konvesional menjadi transaksi yang serba digital dengan proses yang serba mudah, cepat dan praktis.

Proses transaksi tersebut semakin nyaman setelah hadirnya platform e-commerce di Indonesia. Setiap konsumen tidak perlu lagi berkunjung ke toko untuk melihat-lihat produk dan menawar harga. Konsumen hanya perlu mengakses website e-commerce yang dituju. 
Lalu, melihat katalog produk yang disediakan. Kemudian, memilih produk dan memasukkan metode pembayaran. Selanjutnya, pada tahap akhir transaksi yaitu, memilih jasa pengiriman atau ekspedisi yang akan digunakan untuk mengantarkan pesanan.

ERP (Enterprise Resources Planning) adalah seperangkat tools atau software yang digunakan oleh suatu perusahaan untuk dapat mengelola seluruh aktivitas operasional dalam bisnis yang dijalankan oleh perusahaan [1]. Sistem ERP ini mampu memfasilitasi kegiatan bisnis dengan memberikan support informasi secara real-time dan lengkap. Dengan demikian, para pelaku bisnis atau pengusaha dapat dengan mudah untuk mengambil keputusan dengan baik berdasarkan data-data pendukung yang telah dihasilkan oleh sistem ERP ini [2].

E-Commerce merupakan segala bentuk aktivitas perdagangan dengan memanfaatkan sistem elektronik, seperti misalnya jaringan global internet [3]. Dalam bisnis e-commerce melibatkan proses transaksi secara elektrik atau elektronik untuk proses transfer data, pertukaran data, sistem pengolahan data dan inventori produk yang keseluruhan prosesnya dilakukan dengan memanfaatkan teknologi jaringan komputer. Dari pengertian e-commerce tersebut ada beberapa permasalahan yang banyak dialami oleh para pengelola dan manajemen e-commerce, yaitu kesulitan para pengelola untuk mengintegrasikan sistem e-commerce dengan sistem inventory dan sistem purchasing, sehingga banyak kendala dalam operasional sehari-hari, ini diakibat adanya perbedaan platform pada masing-masing sistem tersebut. Dengan demikian perlu adanya standar integrasi untuk sistem e-commerce, salah satunya dengan menggunakan bantuan software ERP (Enterprise Resources Planning) yang berguna untuk mengelola segala aktivitas e-commerce, seperti manajemen pemesanan, mengelola informasi, manajemen persediaan, dan lain sebagainya [4].

Tujuan dari penelitian ini adalah untuk menganalisa, merancang dan menggabungkan suatu sistem e-commerce yang terintegrasi dengan sistem manajemen inventory/persediaan, sistem manajemen purchasing/pembelian dan sistem manajemen penjualan pada e-commerce menggunakan software ERP Odoo 14 yang sudah support untuk ERP Cloud, sehingga sistem dapat dijalankan secara optimal dan dapat mengurangi biaya-biaya operasional yang tidak efisien, serta memudahkan semua departemen untuk berbagi informasi dan berkomunikasi.

\section{LANDASAN TEORI}

\section{A. E-Commerce}

E-Commerce (Elektronik Commerce) atau biasa disebut dengan perdagangan elektronik merupakan seluruh aktivitas yang berkaitan dengan penyebaran, penjualan, pembelian, pemasaran produk (baik berupa barang maupun jasa), dengan memanfaatkan teknologi jaringan komunikasi seperti jaringan internet, saluran televisi, ataupun jaringan lainnya [3]. Secara singkat e-commerce merupakan suatu proses pembelian maupun penjualan berbagai macam produk secara elektronik [5]. e-commerce sendiri semakin berkembang pesat beberapa tahun belakangan ini, serta perlahan mulai menggantikan toko konvensional atau tradisional (toko offline).

\section{B. Enterprise Resource Planning}

ERP (Enterprise Resource Planning) dapat digambarkan sebagai suatu konsep untuk merencanakan serta mengelola sumber daya organisasi atau perusahaan agar dapat diperoleh manfaat secara maksimal, sehingga menghasilkan suatu nilai tambah bagi pihak yang berkepentingan atas suatu organisasi atau perusahaan tersebut [6]. ERP biasanya berupa suatu sistem kerja atau proses bisnis yang didukung oleh tools/software yang terintegrasi untuk organisasi atau perusahaan untuk proses perencanaan dan pengelolaan sumber daya (resource), sehingga dapat mencapai suatu tujuan/goal organisasi atau perusahaan. 


\section{Implementasi ERP}

Saat ini, terdapat tiga tipe pengembangan ERP yang banyak diimplementasikan organisasi atau perusahaan, yaitu on-premise (konvensional), cloud, dan hybrid.
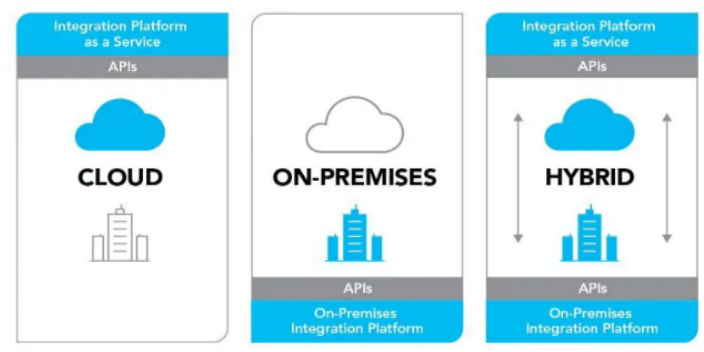

Gambar 1. Jenis Implementasi ERP [7]

1. Cloud ERP merupakan ERP berbasis cloud yang tidak mewajibkan organisasi atau perusahaan untuk dapat membangun infrastruktur yang dibutuhkan untuk proses penyimpanan data, karena semua proses data akan disimpan dalam cloud sistem. Pada proses Implementasinya, tipe ERP ini hanya membutuhkan biaya, waktu, dan tenaga yang jauh lebih kecil, jika dibandingkan dengan tipe ERP yang masih tradisional. Dengan demikian, tipe ERP ini banyak digunakan oleh UKM (Usaha Kecil dan Menengah) atau bahkan beberapa organisasi atau perusahaan e-commerce besar [8].

2. On-Premise ERP merupakan tipe ERP yang mengharuskan organisasi atau perusahaan untuk memiliki infrastruktur berupa perangkat keras seperti server, perangkat jaringan dan lain sebagainya, dengan demikian akan membutuhkan pemeliharaan dan biaya yang relatif lebih besar, sehingga tipe ERP konvensional ini lebih banyak digunakan oleh organisasi atau perusahaan berskala besar [9].

3. Hybrid ERP merupakan tipe ERP yang memungkinkan organisasi atau perusahaan untuk menjalankan perangkat lunak ERP atau software ERP mereka dibawah kendali organisasi atau perusahaan itu sendiri dengan infrastruktur berupa server dengan sebagian proses penyimpanan data disimpan pada cloud sistem.

\section{Odoo 14 (Open ERP)}

Odoo 14 (Open ERP) adalah aplikasi ERP (Enterprise Resources Planning) berbasis web yang modern dan lengkap yang didistribusikan secara open source atau gratis. Odoo 14 (Open $E R P)$ dirancang dengan menggunakan teknologi framework open object yang memiliki kekuatan pada arsitektur MVC (Model View Controller), workflow atau alur kerja proses bisnis yang fleksibel dan mudah dilakukan custom, serta memiliki GUI yang dinamis dan memiliki sistem pelaporan yang dapat dikustomisasi sesuai dengan kebutuhan organisasi atau perusahaan [2].

Odoo 14 merupakan aplikasi berupa web yang dibangun dengan menggunakan bahasa pemograman Phyton, XML, dan JavaScript serta menggunakan DBMS atau database PostgreSQL [10]. Odoo 14 ditujukan kepada organisasi atau perusahaan yang memiliki keinginan untuk meningkatkan performansi dan kualitas dalam bidang manajemen proses bisnis.

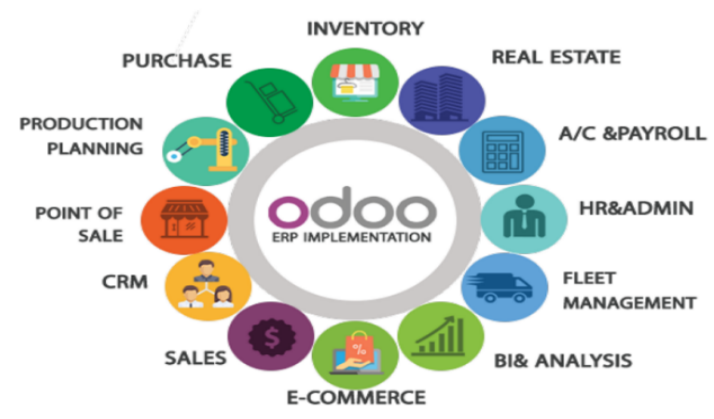

Gambar 2. Integrasi antar modul Odoo [4]

\section{METODE PENELITIAN}

Untuk menganalisa dan merancang sistem $e$ commerce berbasis cloud enterprise resource planning menggunakan odoo 14, maka pada penelitian ini akan menggunakan alur tahapan penelitian sebagai berikut: 


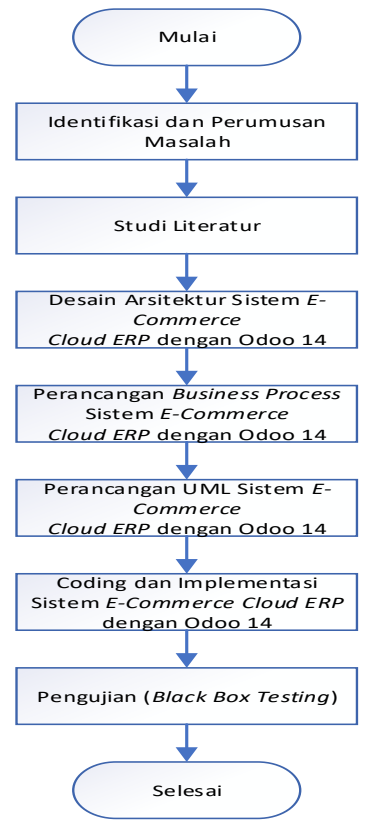

Gambar 3. Alur Tahapan Penelitian

Pada gambar 3 terlihat alur tahapan penelitian yang dimulai dengan tahapan identifikasi dan perumusan masalah yang banyak dialami oleh para pengelola dan manajemen e-commerce terkait kendala untuk mengintegrasikan sistem $e$ commerce dengan sistem inventory dan sistem purchasing yang bersifat multiplatform. Lalu tahapan berikutnya dilakukan studi literatur terkait integrasi sistem e-commerce dengan cloud ERP dari beberapa referensi penelitian sejenis dengan menggunakan odoo.

Kemudian tahapan berikutnya yaitu, membuat desain arsitektur sistem e-commerce berbasis cloud ERP dengan odoo 14 yang menjadi usulan solusi arsitektur dalam mengatasi integrasi sistem multiplatform. Selanjutnya dilakukan perancangan Business Process dan perancangan UML (Unified Modelling Language), lalu pada tahapan berikutnya dilanjukan dengan coding dan implementasi sistem e-commerce cloud ERP dengan odoo 14. Lalu, yang terakhir dilakukan proses pengujian sistem dengan Black Box Testing.

\section{HASIL DAN PEMBAHASAN}

\section{A. Desain Sistem E-Commerce Cloud ERP dengan Odoo 14}

Pada penelitian ini, diusulkan suatu solusi desain arsitektur sistem e-commerce dengan memanfaatkan teknologi cloud system, adapun desain arsitekturnya sebagai berikut:

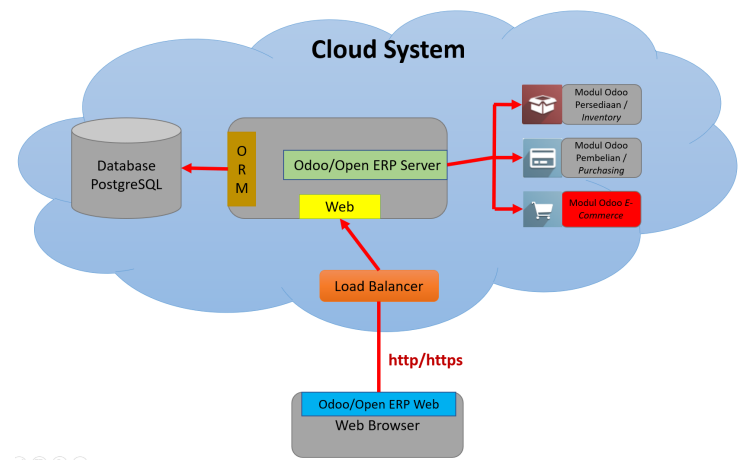

Gambar 4. Desain Arsitektur Sistem E-Commerce Cloud ERP dengan odoo 14

Pada gambar 4 terlihat desain arsitektur cloud sistem e-commerce yang terdiri dari database postgresql, odoo server yang dikomunikasikan dengan beberapa modul ERP odoo seperti modul e-commerce, purchasing dan inventory. Kemudian untuk komunikasi antara database postgresql dan aplikasi odoo yang terdapat pada odoo server menggunakan ORM (Object Relational Mapping). ORM secara umum berfungsi untuk menghubungkan OOP dengan database, jadi kita tidak perlu menuliskan syntax SQL secara langsung untuk mengolah data di database (meskipun itu bisa dilakukan). Selain itu ORM juga berfungsi untuk keamanan, karena melalui ORM akan dilakukan filter security sesuai privilege user yang mengakses.

Lalu pada bagian web service yang terdapat pada odoo server dihubungkan dengan load balancer. Fungsi dari load balancer yaitu untuk membagi beban traffic suatu aplikasi atau server. Dengan load balancer, beban traffic akan dibagi ke beberapa jalur koneksi, sehingga tidak akan membebani kinerja server. Hal ini akan mempercepat waktu respons pada server dan mencegahnya server dari mekanisme overloading. Dengan begitu, kinerja server akan 
lebih jauh lebih optimal dan tidak peduli berapa banyak traffic yang masuk.

B. Flowchart Business Process Sistem ECommerce Berbasis Cloud ERP dengan Odoo

Pada penelitian ini, diusulkan suatu business process sistem e-commerce berbasis Cloud ERP
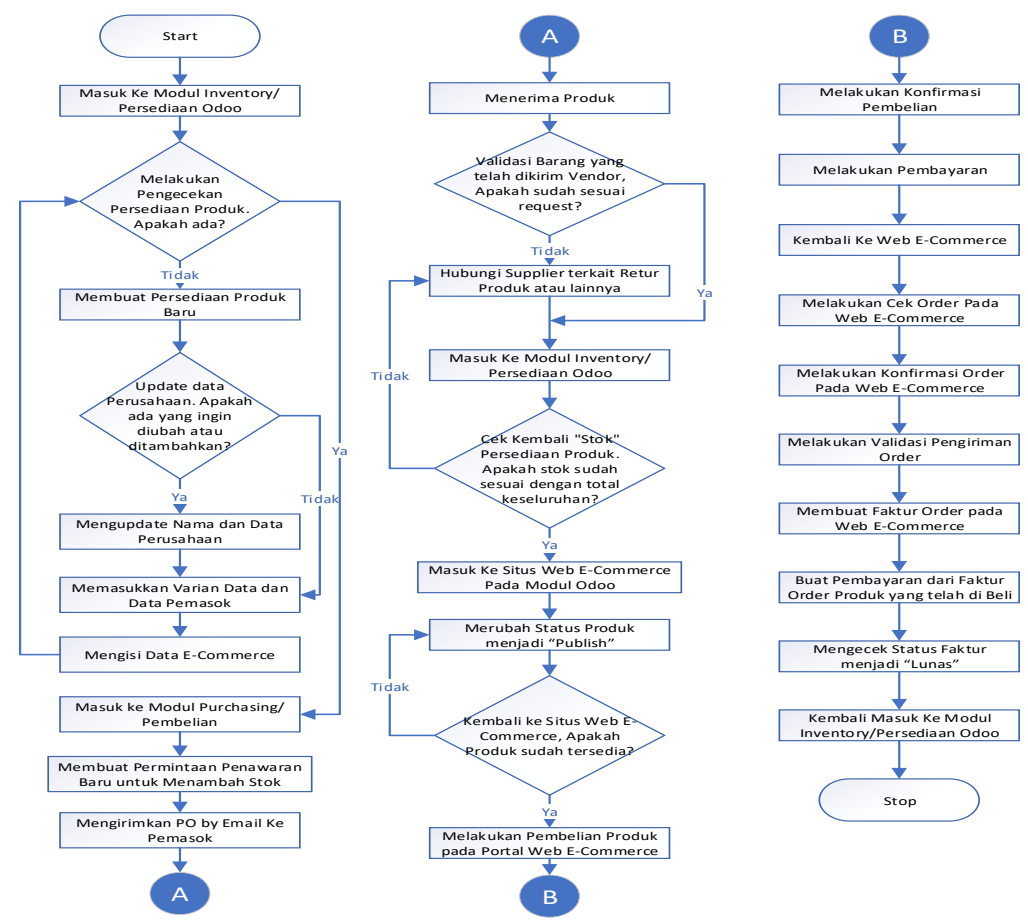

Gambar 5. Flowchart Business Process Sistem E-Commerce Berbasis Cloud ERP dengan Odoo

\section{Use Case Diagram Sistem E-Commerce}

Berbasis Cloud ERP dengan Odoo

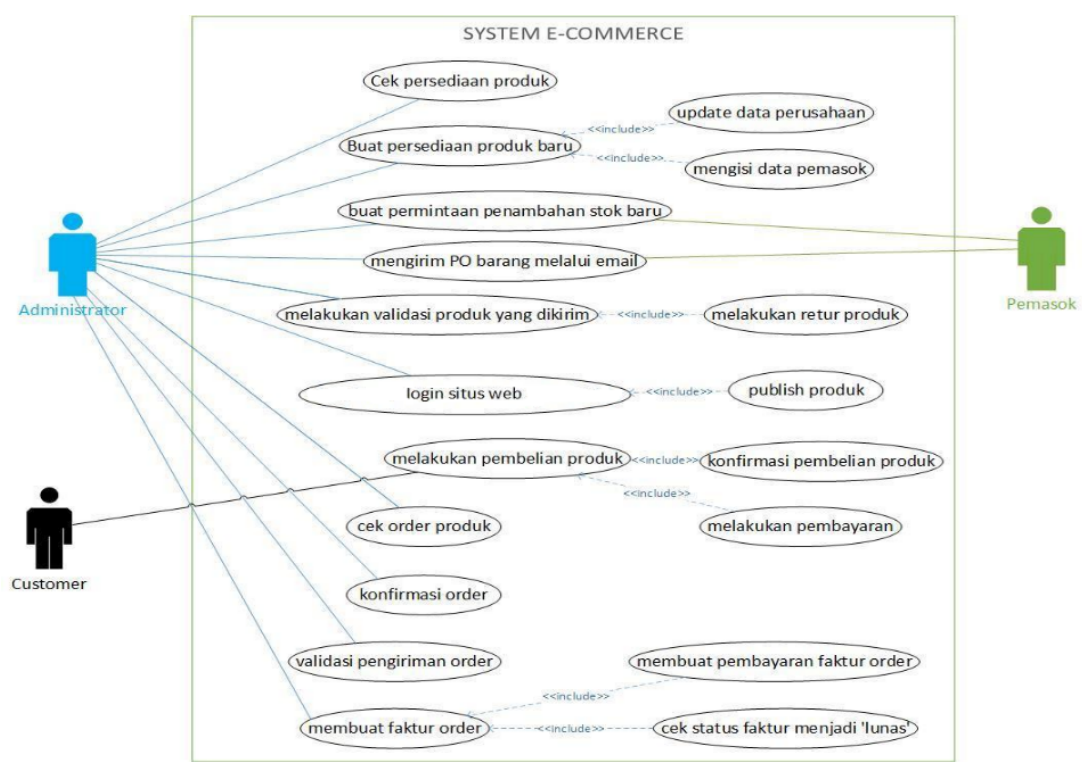

Gambar 6. Use Case Diagram Sistem E-Commerce Berbasis Cloud ERP dengan Odoo 
Pada use case diagram diatas, terdapat boundary yang berisi proses sistem e-commerce berbasis cloud ERP dengan odoo. Lalu pada use case diagram tersebut, memiliki tiga aktor yang berpengaruh dalam proses bisnis pada sistem $e$ commerce. Tiga aktor tersebut adalah administrator, pemasok/supplier, dan customer. Pada use case diagram juga terlihat beberapa proses seperti, pengecekan stok persediaan, melakukan pembelian stok kepada pemasok, dan pembelian produk oleh customer.

\section{Sequence Diagram Sistem E-Commerce Berbasis Cloud ERP dengan Odoo}

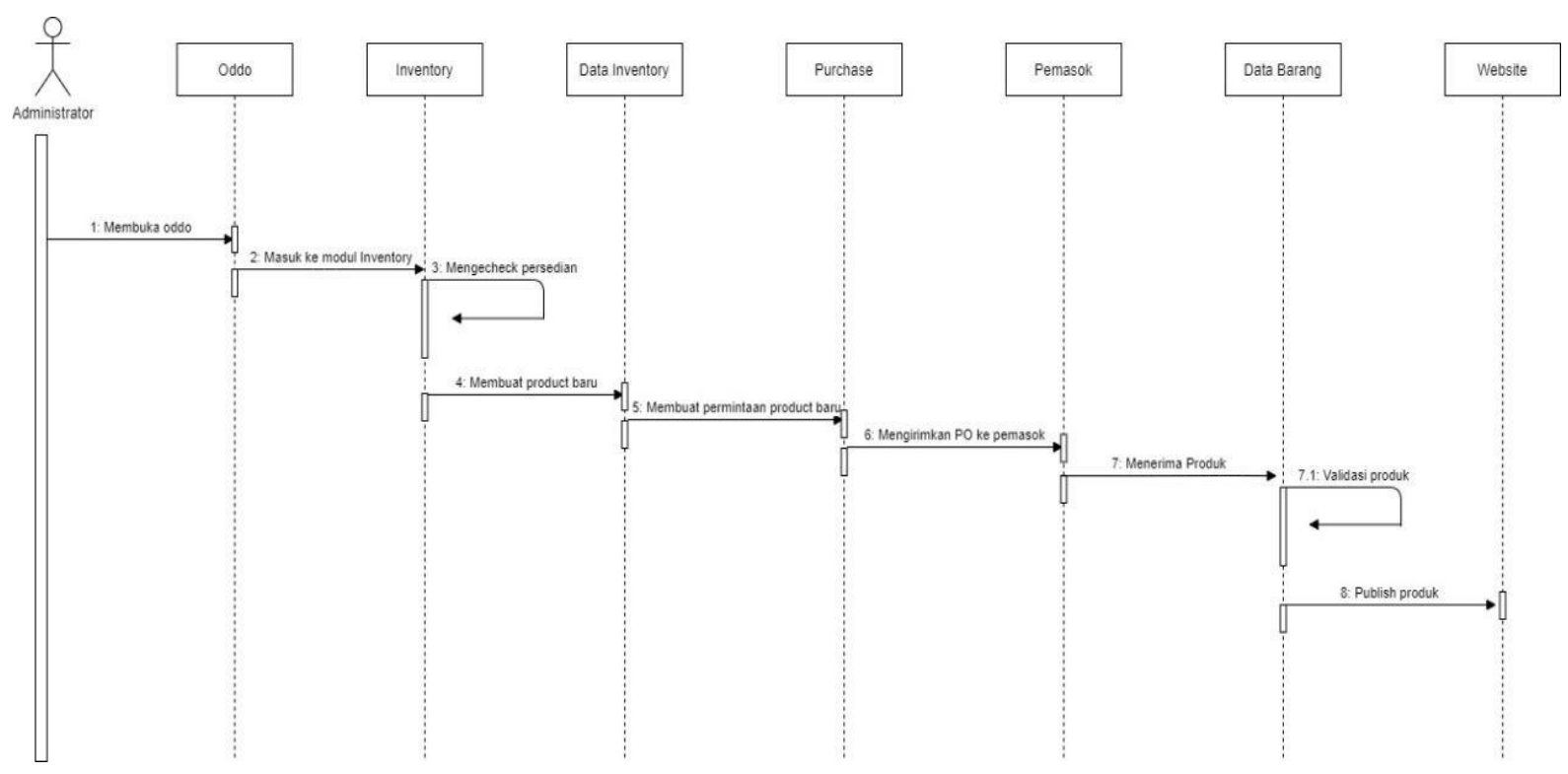

Gambar 7. Sequence Diagram Sistem E-Commerce Berbasis Cloud ERP dengan Odoo

Pada sequence diagram pada gambar 7 menjelaskan tentang proses yang dilalui oleh administrator. Pada proses awal, administrator masuk atau membuka aplikasi odoo melalui objek odoo. Proses ke-2 menuju objek inventory yaitu proses administrator masuk ke modul inventory. Proses ke-3 yang dijalankan administrator yaitu cek persediaan produk pada objek inventory. Kemudian pada proses ke-4 yaitu membuat produk baru pada objek data inventory. Lalu pada proses ke-6 yaitu mengirimkan PO (Purchase Order) produk pada objek pemasok. Lalu pada proses ke-7, administrator menerima produk pada objek data barang. Kemudian pada proses ke-7.1, administrator memvalidasi atau cek produk pada objek data barang. Selanjutnya pada proses ke- 8 yaitu administrator mem-publish produk yang berada pada objek website.

\section{E. Hasil}

Berikut ini merupakan hasil dari pengujian sistem e-commerce dengan memanfaatkan teknologi cloud enterprise resource planning dengan menggunakan platform ERP odoo 14:

\section{Antarmuka Halaman Login Sistem E- Commerce}

Pada halaman login utama sistem e-commerce berbasis cloud dengan odoo 14 dapat diakses oleh user maupun administrator yang telah diatur atau di set privilege-nya oleh 
administrator sistem. Berikut tampilan halaman login nya.

\begin{tabular}{l} 
Email \\
Kata Sandi \\
Kandi Log masuk Atur Ulang Kata Sandi \\
\hline Don't have an account?
\end{tabular}

Gambar 8. Antarmuka Halaman Login Sistem ECommerce

2. Antarmuka Halaman Utama Sistem ECommerce Cloud ERP

Pada halaman utama sistem e-commerce cloud erp merupakan halaman yang akan menampilkan produk yang dijual secara online dengan beberapa kategori barang yang dapat di custom oleh administrator, serta pada halaman ini juga telah terintegrasi dengan modul inventory dan purchasing.

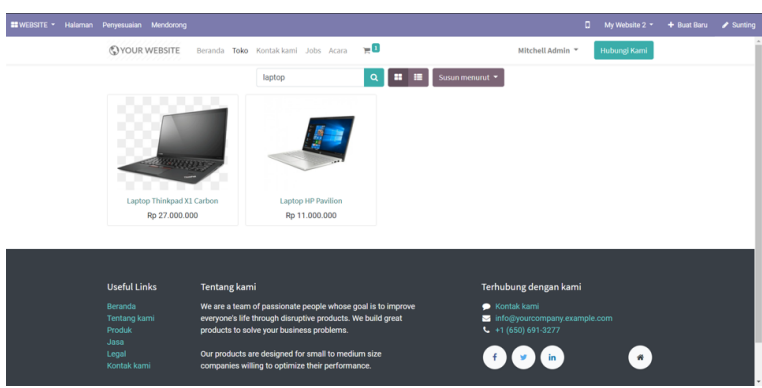

Gambar 9. Antarmuka Halaman Utama Sistem ECommerce Cloud ERP

3. Antarmuka Halaman Inventory pada Cloud ERP

Pada halaman inventory merupakan halaman yang akan menampilkan beberapa stok produk berikut dengan jumlah/total stok yang tersedia digudang. Pada halaman ini juga telah terintegrasi dengan para supplier/vendor terkait pembelian stok produk.

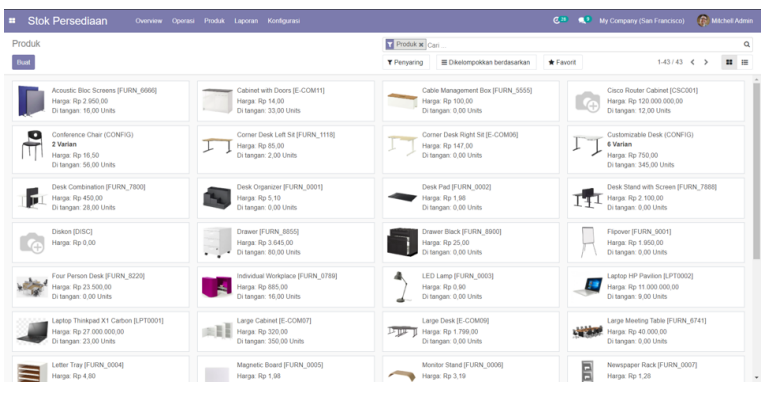

Gambar 10. Antarmuka Halaman Inventory pada Cloud ERP

\section{Antarmuka Halaman Purchasing pada Cloud} ERP

Pada halaman purchasing digunakan sebagai halaman untuk melakukan proses pembelian stok produk kepada supplier/vendor. Pada halaman ini juga dapat menampilkan halaman PO (Purchase Order) dari transaksi pembelian, serta pada halaman ini juga sudah terintegrasi dengan SMTP email, sehingga pengelola dapat dengan mudah berkomunikasi langsung dengan supplier/vendor.

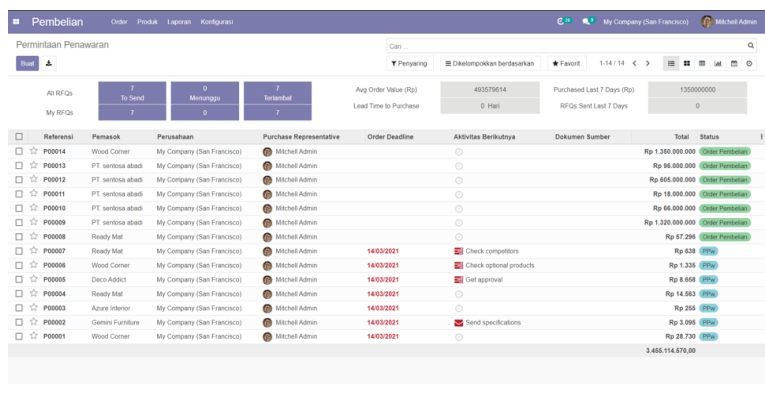

Gambar 11. Antarmuka Halaman Purchasing pada Cloud ERP

\section{Hasil Pengujian Black Box}

Pengujian terhadap sistem e-commerce berbasis cloud enterprise resource planning menggunakan odoo 14 ini dengan metode pengujian black box yang memiliki test case/kelas uji sebanyak 12 parameter. Adapun hasil pengujian black box pada penelitian ini sebagai berikut.

Tabel 1. Hasil Pengujian Black Box 


\begin{tabular}{|c|c|c|c|c|}
\hline No & $\begin{array}{l}\text { Test Case } \\
\text { (Kelas Uji) }\end{array}$ & Skenario Uji & $\begin{array}{c}\text { Hasil yang } \\
\text { Diharapkan }\end{array}$ & $\begin{array}{l}\text { Valid } \\
(\checkmark) \\
\text { atau } \\
\text { Tidak } \\
\text { Valid } \\
(x)\end{array}$ \\
\hline 1 & $\begin{array}{l}\text { Menampilkan } \\
\text { halaman login }\end{array}$ & $\begin{array}{l}\text { Melakukan login } \\
\text { (mekanisme } \\
\text { login user } \\
\text { maupun admin) }\end{array}$ & $\begin{array}{l}\text { Menampilkan } \\
\text { halaman } \\
\text { dashboard user } \\
\text { maupun admin } \\
\text { pada sistem } e- \\
\text { commerce }\end{array}$ & $\checkmark$ \\
\hline 2 & $\begin{array}{l}\text { Menampilkan } \\
\text { halaman sistem } \\
\text { e-commerce } \\
\text { pada cloud erp }\end{array}$ & $\begin{array}{l}\text { Memilih sistem } \\
\text { e-commerce } \\
\text { pada cloud erp }\end{array}$ & $\begin{array}{l}\text { Menampilkan } \\
\text { halaman utama } \\
\text { sistem e- } \\
\text { commerce }\end{array}$ & $\checkmark$ \\
\hline 3 & $\begin{array}{l}\text { Menampilkan } \\
\text { halaman } \\
\text { shopping chart } \\
\text { pada cloud erp }\end{array}$ & $\begin{array}{c}\text { Memasukkan } \\
\text { beberapa produk } \\
\text { ke shopping } \\
\text { chart }\end{array}$ & $\begin{array}{l}\text { Menampilkan } \\
\text { beberapa produk } \\
\text { yang dipesan } \\
\text { pada halaman } \\
\text { shopping chart }\end{array}$ & $\checkmark$ \\
\hline 4 & $\begin{array}{l}\text { Menampilkan } \\
\text { halaman } \\
\text { pembayaran } \\
\text { untuk sistem e- } \\
\text { commerce pada } \\
\text { cloud erp }\end{array}$ & $\begin{array}{c}\text { Memilih } \\
\text { beberapa metode } \\
\text { pembayaran }\end{array}$ & $\begin{array}{c}\text { Menampilkan } \\
\text { halaman status } \\
\text { pembayaran }\end{array}$ & $\checkmark$ \\
\hline 5 & $\begin{array}{l}\text { Menampilkan } \\
\text { halaman } \\
\text { inventory/stok } \\
\text { pada cloud erp }\end{array}$ & $\begin{array}{c}\text { Menampilkan } \\
\text { total stok produk } \\
\text { yang telah dibeli } \\
\text { dari } \\
\text { supplier/vendor }\end{array}$ & $\begin{array}{l}\text { Menampilkan } \\
\text { halaman } \\
\text { manajemen stok } \\
\text { produk, berikut } \\
\text { detail setiap arus } \\
\text { produk untuk } \\
\text { setiap transaksi. }\end{array}$ & $\checkmark$ \\
\hline 6 & $\begin{array}{l}\text { Menampilkan } \\
\text { halaman } \\
\text { purchasing } \\
\text { pada cloud erp }\end{array}$ & $\begin{array}{l}\text { Melakukan } \\
\text { proses } \\
\text { pembelian stok } \\
\text { produk kepada } \\
\text { supplier/vendor }\end{array}$ & $\begin{array}{l}\text { Menampilkan } \\
\text { halaman } \\
\text { manajemen PO } \\
\text { (Purchase } \\
\text { Order) dari } \\
\text { transaksi } \\
\text { pembelian }\end{array}$ & $\checkmark$ \\
\hline 9 & $\begin{array}{c}\text { Menampilkan } \\
\text { halaman } \\
\text { konfigurasi } \\
\text { account }\end{array}$ & $\begin{array}{c}\text { Memilih menu } \\
\text { konfigurasi } \\
\text { account }\end{array}$ & $\begin{array}{l}\text { Menampilkan } \\
\text { halaman } \\
\text { manajemen } \\
\text { account }\end{array}$ & $\checkmark$ \\
\hline 10 & $\begin{array}{l}\text { Menampilkan } \\
\text { halaman change } \\
\text { password } \\
\text { account }\end{array}$ & $\begin{array}{l}\text { Memilih change } \\
\text { password menu } \\
\text { account }\end{array}$ & $\begin{array}{l}\text { Menampilkan isi } \\
\text { dari halaman } \\
\text { change password } \\
\text { menu account }\end{array}$ & $\checkmark$ \\
\hline 11 & $\begin{array}{c}\text { Keluar dari } \\
\text { sistem } e- \\
\text { commerce pada } \\
\text { cloud } \text { erp }\end{array}$ & $\begin{array}{c}\text { Memilih logout } \\
\text { pada menu } \\
\text { account }\end{array}$ & $\begin{array}{l}\text { Keluar dari } \\
\text { aplikasi }\end{array}$ & $\checkmark$ \\
\hline 12 & $\begin{array}{l}\text { Menampilkan } \\
\text { halaman help } \\
\text { Odoo } 14\end{array}$ & $\begin{array}{l}\text { Memilih menu } \\
\text { help Odoo } 14\end{array}$ & $\begin{array}{c}\text { Menampilkan isi } \\
\text { dari halaman } \\
\text { help Odoo } 14\end{array}$ & $\checkmark$ \\
\hline
\end{tabular}

\section{KESIMPULAN DAN SARAN}

\section{A. Kesimpulan}

Berdasarkan penelitian dan hasil pengujian yang dilakukan terhadap sistem e-commerce berbasis cloud enterprise resource planning menggunakan Odoo 14, maka diperoleh kesimpulan sebagai berikut:

1. Dari hasil pengujian black box pada sistem $e$ commerce berbasis cloud enterprise resource planning menggunakan odoo 14, menunjukkan bahwa sistem mempunyai tingkat fungsionalitas yang baik, terlihat dari 12 parameter test case/kelas uji bernilai valid dan semua fungsi yang berada pada sistem dapat bekerja dengan sangat baik, serta sistem sudah dapat memenuhi spesifikasi kebutuhan.

2. Dengan penggunaan platform cloud erp pada sistem e-commerce dapat menghemat pengeluaran infrastruktur, khususnya untuk pembeli server aplikasi, server database serta perangkat jaringan lainnya. Karena pada arsitektur yang diusulkan, semua konfigurasi aplikasi, database, web service dan load balancer dijalankan di cloud system.

3. Penggunaan load balancer pada infrastruktur sistem e-commerce berbasis cloud erp menggunakan Odoo 14 sangat efektif dalam membagi beban traffic menjadi beberapa jalur koneksi. Hal ini dapat mempercepat waktu respons pada cloud server dan mencegahnya dari kondisi overloading.

\section{B. Saran}

Sistem e-commerce berbasis cloud erp ini masih memiliki banyak keterbatasan dan kekurangan, sehingga dibutuhkan beberapa saran yang dapat membangun diantaranya:

1. Pada sistem e-commerce berbasis cloud erp perlu ditambahkan metode pengamanan data tertentu menggunakan algoritma kriptografi seperti simetri, asimetri atupun fungsi hash untuk setiap integrasi sistem antar modul erp dengan sistem third party milik supplier/vendor. 
2. Perlu dilakukan penelitian lebih lanjut terkait dengan backup single cloud pada sistem ecommerce, karena jika sistem cloud bermasalah atau tidak bisa diakses (sistem cloud down), maka sistem e-commerce tidak akan bisa diakses. Dengan demikian dibutuhkan suatu pengembangan arsitektur untuk menangani masalah dari single backup pada sistem cloud tersebut, yaitu salah satunya dengan mengembangkan arsitektur single backup menjadi arsitektur cross cloud backup.

\section{DAFTAR PUSTAKA}

[1] R. G. Hidayat, I. Nuryasin, and W. Suharso, "Implementasi Sistem Informasi Penjualan dan Persediaan Menggunakan webERP Pada Cribo Inc Malang," J. Repos., vol. 2, no. 8, pp. 1067-1074, Aug. 2020, doi: 10.22219/REPOSITOR.V2I8.906.

[2] S.- Suminten, S. Amelia, and I. D. Sintawati, "PENERAPAN ENTERPRISE RESOURSE PLANNING PENJUALAN AKSESORIS BERBASIS ODOO," JSiI (Jurnal Sist. Informasi), vol. 6, no. 1, pp. 69-74, Apr. 2019, doi: 10.30656/JSII.V6I1.1052.

[3] E. A. Wibowo, "PEMANFAATAN TEKNOLOGI ECOMMERCE DALAM PROSES BISNIS," EQUILIBIRIA, vol. 1, no. 1, 2014, doi: 10.33373/JEQ.V1I1.222.

[4] A. Prastyo, R. Rispianda, and C. Nugraha, "RANCANGAN SISTEM INFORMASI TERINTEGRASI DI PT. MTE BERBASIS SISTEM ENTERPRISE RESOURCE PLANNING MENGGUNAKAN SOFTWARE ODOO," REKA Integr., vol. 4, no. 1, Jan. 2016, Accessed: Aug. 28, 2021.

[Online].

Available: https://ejurnal.itenas.ac.id/index.php/rekaintegra/articl e/view/1060.

[5] A. Ridho, R. Rispianda, and G. P. Liansari, "IMPLEMENTASI SISTEM MATERIAL REQUIREMENT PLANNING (MRP) DAN ECOMMERCE BERBASIS ENTERPRISE RESOURCE PLANNING (ERP) DI PT.XYZ MENGGUNAKAN SOFTWARE ODOO," REKA Integr., vol. 3, no. 3, Jul. 2015, Accessed: Aug. 28, 2021. [Online]. Available: https://ejurnal.itenas.ac.id/index.php/rekaintegra/articl e/view/867.

[6] D. A. Rimen and R. Akbar, "Penerapan Enterprise Resource Planning (ERP) dan Pengelolaan Hubungan dengan Pelanggan untuk Sistem Informasi Penjualan pada Toko SOVIAH," J. Nas. Teknol. dan Sist. Inf., vol. 2, no. 2, pp. 85-96, Aug. 2016, doi: 10.25077/TEKNOSI.V2I2.2016.85-96.

[7] "Pengertian ERP (Enterprise Resource Planning) Software Secara Lengkap." https://www.hashmicro.com/id/blog/pengertian-erpsoftware/ (accessed Aug. 28, 2021).

[8] A. Asniar and S. K. Sari, "Pemanfaatan Cloud Computing untuk Enterprise Resources Planning di Indonesia," J. INFOTEL, vol. 7, no. 1, pp. 75-82, May 2015, doi: 10.20895/INFOTEL.V7I1.33.

[9] A. Nakkeeran, M. Niranga, and R. Wickramarachchi, "A Model for On-Premises ERP System and Cloud ERP Integration," Accessed: Aug. 28, 2021. [Online]. Available: www.gartner.com.

[10] V. K. E. Koeswanto, Y. Yulia, and R. Adipranata, "Perancangan Modul Penggajian Berbasis Odoo," $J$. Infra, vol. 4, no. 1, pp. 277-281, Feb. 2016, Accessed: Aug. 28, 2021. [Online]. Available: http://publication.petra.ac.id/index.php/teknikinformatika/article/view/4076. 